\title{
PENERAPAN SISTEM INFORMASI MANAJEMEN DI SEKOLAH
}

\author{
Mutiara Islami Putri
}

17002020

Email : mutiaraislami2017@gmail.com

\begin{abstract}
Abstrak
Tujuan penulisan ini adalah untuk mengetahui dan memperoleh informasi mengenai peran sistem informasi manajemen di suatu sekolah atau lembaga pendidikan, dan untuk mengetahui bagaimana pelaksanaan atau penerapan dari sistem informasi manajemen itu sendiri. Terdapat beberapa masalah dalam penerapan sistem informasi manajemen di sekolah seperti adanya pegawai yang kurang mampu dalam teknologi,maka dari itu dangat diperlukan peran sistem informasi agar dapat membantu setiap pekerjaan yang dilakukan dalam sebuah organisasi
\end{abstract}

Kata Kunci : peran, sistem informasi manajemen, sekolah

\section{LATAR BELAKANG}

Perkembangan teknologi informasi yang berkembang pesat serta pemanfaatannya yang luas pada saat ini membuka peluang bagi pendayaguna informasi secara cepat dan tepat. Dengan pemanfaatan teknologi Sistem Informasi Manajemen (SIM) akan dapat mengurangi tahap proses kerja dalam organisasi.

Pemanfaatan dari perkembangan teknologi informasi inilah yang dapat membantu setiap pekerjaan yang dilakukan dalam sebuah organisasi. Salah satu pemanfaatan SIM yang bisa di aplikasikan di organisasi adalah Sistem Informasi Manajemen Kepegawaian. Hal ini tentu saja memiliki suatu tujuan untuk dapat memudahkan pekerjaan setiap pimpinan maupun pegawai dalam mendapatkan informasi terkait semua hal yang berubungan dengan pegawai ataupun guru di sekolah. Pemanfataan sistem inilah sangat diperlukan bagi setiap sekolah ataupun organisasi agar setiap pekerjaan dapat dilakukan dengan baik.

\section{PEMBAHASAN}

\section{Pengertian Sistem Informasi Manajemen}


Sistem Informasi Manajemen adalah suatu sistem dalam sebuah perusahaan yang bertujuan untuk menyimpan, mengumpulkan, dan mengelola data dan suatu informasi yang nantinya akan digunakan oleh seseorang demi tercapainya hasil pekerjaan yang baik.

Pengertian Sistem Informasi menurut Husain dan Wibowo[ CITATION RIZ13 \1 1057 ] adalah sebagai berikut : Sistem Informasi adalah seperangkat komponen yang saling berhubungan yang berfungsi mengumpulkan, memproses, menyimpan dan mendistribusikan informasi untuk mendukung pembuatan keputusan dan pengawasan dalam organisasi”.

Sistem informasi manjemen ini sangat penting dirancang dalam suatu perusahaan, karena dengan adanya sistem informasi ini dapat menyediakan informasi penting bagi suau perusahaan atau lembaga pendidikan.

\section{Tujuan Sistem Informasi Manajemen}

1. Sistem informasi manajemen bertujuan untuk menyediakan informasi yang diperlukan oleh setiap orang yang akan digunakan untuk mengolah data.

2. Sistem informasi manajemen bertujuan untuk menyediakan informasi yang akan digunakan untuk pengambilan keputusan

3. Bertujuan untuk memenuhi semua kebutuhan informasi yang dibutuhkan oleh setiap manajer atau kepala sekolah di suatu sekolah atau setiap lembaga pendidikan.

\section{Manfaat Sistem Informasi Manajemen}

Apabila sistem informasi ini bisa dirancang dengan baik, akan memunculkan manfaat yang banyak bagi perusahaan. Dengan adanya sistem informasi manajemen ini banyak memunculkan manfaat bagi suatu organisasi dan suatu lembaga pendidikan diantaranya adalah sebagai berikut :

1. Untuk memudahkan para pegawai di suatu lembaga pendidikan untuk mengelola, menyimpan informasi yang akan diperlukan

2. Untuk memudahkan melakukan perencanaan, pengendalian, pelaksanaan, agar pekerjaan dapat mudah terselesaikan.

3. Meningkatkan produktivitas dan penghematan biaya dalam organisasi

4. Dapat memudahkan dan membantu seorang pegawai atau manajer dalam pengambilan keputusan

\section{Penerapan sistem informasi manajemen}


Menurut sabandi ada beberapa penerapan sistem informasi manajemen

1. Dilihat dari aspek input

Aktivitas input dalam sistem informasi manajemen sangat penting dan merupakan langkah utama dalam penerapan sistem informasi manajemen, karena aktivitas input ini merupakan proses memasukan data ke dalam sebuah sistem yang nantinya akan mendapat informasi yang digunakan untuk organisasi.

Menurut Sutabri [ CITATION Git18 \1 1057 ] input adalah energi yang dimasukkan ke dalam sistem disebut masukan sistem, yang dapat berupa pemeliharaan (maitenance input) dan sinyal (signal input). Dalam aktivitas input ini kita harus memperhatikan beberapa hal diantaranya adalah pengumpulan data, perangkat keras, perangkat lunak, jaringan atau internet, sumber daya manusia dan prosedur.

2. Dilihat dari aspek proses

Proses adalah suatu prosedur dari memasukkan data atau masukan menjadi keluaran atau output. Agar kita mendapat keluaran dengan baik tentu saja kita harus melakukan prsoes yang baik juga yang diawali dengan proses memasukan data hingga menjadi keluaran. Dalam aktivitas proses ini kita perlu melakukan beberapa cara yaitu mengolah data yang dimasukan tadi dan menyimpannya. Sedikit materi mengenai pengolahan data yang disampaikan oleh siagian [ CITATION Git18 \1 1057] pengolahan data ialah sebuah tahapan untuk mengubah bentuk dan arti dari data menjadi informasi serta bisa digunakan dalam menunjang berbagai kegiatan manajemen bisnis termasuk kegiatan mengambil keputusan.

3. Dilihat dari aspek output

Output adalah aktivitas yang sudah dilakukan dalam proses yang telah dilakukan sebelumnya. Hasil yang di dapat pada output ini adalah sebuah informasi. Jadi, dari awal kita memasukan data hingga data tersebut di proses akan berubah menjadi suatu keluaran yang isinya adalah sebuah informasi.

Untuk memanfaatkan informasi tersebut, seorang pegawai di sekolah atau organisai harus memperhatikan beberapa kriteria yaitu adanya kepadatan informasi, informasi yang relevan, akurat dan informasi yang jelas.

Sutabri[ CITATION Git18 $\backslash 11057$ ] informasi yaitu data yang telah di diolah atau diinterpretasi untuk digunakan dalam proses pengambilan keputusan. Informasi yang akurat akan mudah digunakan oleh pengguna SIMPEG maupun organisasi dalam memenuhi kebutuhan akan informasi yang diperlukan. 


\section{PENUTUP}

Jadi, sistem informasi manajemen adalah suatu sistem yang memudahkan pegawai atau seseorang dalam perusahaan untuk menyimpan, mengelola suatu informasi yang berguna bagi perusahaan tersebut. . Hal ini tentu saja memiliki suatu tujuan untuk dapat memudahkan pekerjaan setiap pimpinan maupun pegawai dalam mendapatkan informasi terkait semua hal yang berubungan dengan pegawai ataupun guru di sekolah. Pemanfataan sistem inilah sangat diperlukan bagi setiap sekolah ataupun organisasi agar setiap pekerjaan dapat dilakukan dengan baik.

\section{REFERENSI}

MACHMUD, R. (2013). PERANAN PENERAPAN SISTEM INFORMASI MANAJEMEN TERHADAP EFEKTIVITAS KERJA PEGAWAI LEMBAGA PEMASYARAKATAN NARKOTIKA (LAPASTIKA) BOLLANGI KABUPATEN GOWA. Jurnal Capacity STIE AMKOP Makassar, 13.

Sabandi, G. B. (2018). PERSEPSI PEGAWAI TERHADAP PENERAPAN SISTEM INFORMASI MANAJEMEN KEPEGAWAIAN (SIMPEG) DI BADAN KEPEGAWAIAN DAERAH PROVINSI SUMATERA BARAT). Jurnal Bahana Manajemen P , 8. 